\title{
ACCURACY IN THE GEOMETRICAL CHARACTERISTICS OF STEP SHAFT DEFLECTION COMPUTING BY REDUCTION METHOD
}

\author{
Stanislav Kotšmíd, Ján Marienčík, Pavel Beňo, Marian Minárik, Dražan Kozak, Pejo Konjatić
}

Original scientific paper

The paper deals with the computing method of step shaft deflection in an intended place by using the diameter reduction method. This method is analytically studied on the selected shaft shape at different variants of diameters and individual span lengths, where values of deflection are compared with computed values without using this reduction. These values were selected as exact, which was verified by numerical computing in PTC Creo Simulate software. The relative percentage errors are graphically interpreted, and the contribution also deals with the creation of limiting conditions for their use. The aim is to point at limiting conditions of using this method, which may not be always met in practice. It also points to possible failures of this method, which is shown in an incorrect dimension of the shaft, influencing the reliability and safety of operation.

Keywords: deformation; errors relative percentage; shaft deflection; step shaft

Točnost geometrijskih karakteristika određivanja progiba stupnjevane osovine dobivenih metodom redukcije

Izvorni znanstveni članak Ovaj rad se bavi računalnom metodom određivanja progiba stupnjevane osovine koristeći metodu redukcije promjera.Ova metoda je proučavana analitički na odabranom obliku vratila u različitim varijantama promjera i duljine pojedinih raspona, gdje su vrijednosti progiba uspoređivane s izračunatim vrijednostima bez tog smanjenja. Te vrijednosti su odabrane kao točne i verificirane su numerički proračunom u PTC Creo softveru za simulaciju. Relativni postotci pogreške su interpretirani grafički, a u ovom radu su istraženi i ograničavajući uvjeti za njihovo korištenje. Cilj rada je ukazati na ograničavajuće uvjete korištenja ove metode, koja se ne može uvijek susresti u praksi. Isto tako u radu se ukazuje na moguće propuste koji se mogu učiniti u ovom postupku, i to je prikazano na pogrešnoj dimenziji osovine koja utječe na pouzdanost i sigurnost rada.

Ključne riječi: deformacije; progib vratila; relativni postotak pogreške; stupnjevana osovina

\section{Introduction}

One of the basic tasks to be solved in elasticity and strength is to ask the question, how to compute dimensions of constructional components in order to reliably resist load during their duty. The aim is to exclude the possibility of arising limiting conditions, concretely losing of loading capacity, respectively hindering standard construction due to an excessive deflection.

In practice, many cases may be encountered, where deflection of individual component parts is more important for dimensioning than their strength. One of these components is the shaft, the basic component which enables rotational motion and torsion moment transferring [1]. When strength dimensioning, obtained dimensions fulfil the condition of strength, but deflection caused by outside load may be so high that it can damage the other components of mechanism such as gears and bearings, where the shaft is their carrying element.

Moreover, in tooling applications, where accurate work to the hundredths of millimetres is expected, this aspect cannot be ignored, because the shaft deflection has an effect on the position of cutting edges towards piece and therefore to tooling accuracy [2]. Also at the incorrectly computed shaft deflection, the excessive vibrations and noise can appear. These vibrations can help the formation and extension of cracks which can change the value of natural frequency [3]. These vibrations also affect buildings, machinery, equipment, health and safety of people operating them [4]. Therefore, the control of deflection and deflection line slewing in defined places is important.

In practical applications, considering the shape of shaft, step shaft is most commonly encountered [5]. To compute its deformation, different methods are used, for instance Castigliano or Vereshchagin method, method of direct integration, moment area method, or initial parameters method $[6,7,8]$. When solving mechanics tasks, different numerical methods are also useful.

In literature, it can be found that the method of diameter reduction is one of the ways of computing simplification. This method is characterised by reduction of individual diameters into one selected diameter, which markedly simplifies the task. This simplification may cause great relative errors as a result of specific conditions infringement. In this paper, different diameter and length variants of the specified shaft shape and deformation computing with and without using of reduction will be shown. The contribution will bring a list of conditions that allow use of the method of reduction, also with expressing of relative percentage errors at the computing model.

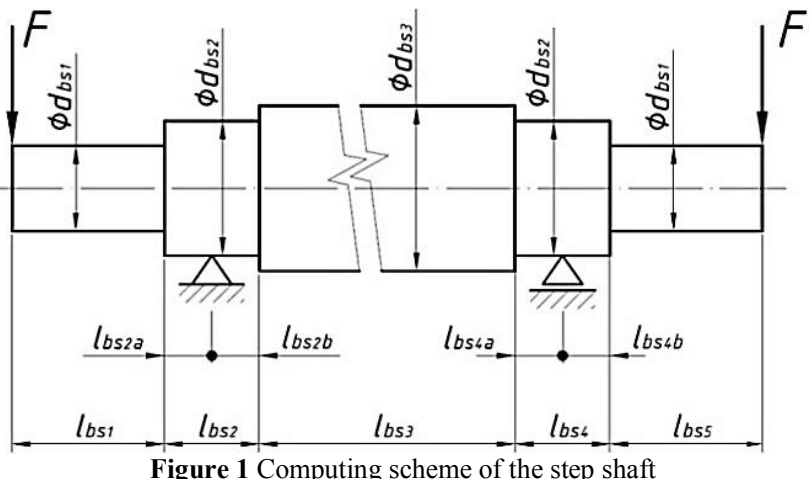

\section{Method}

The diameter reduction of the step shaft is one of the methods how a computing model can be simplified. This 
method is based on calculation of the step shaft compared to the shaft with a uniform diameter, where changing of individual span lengths is caused. The step shaft was selected in a shape according to Fig. 1.

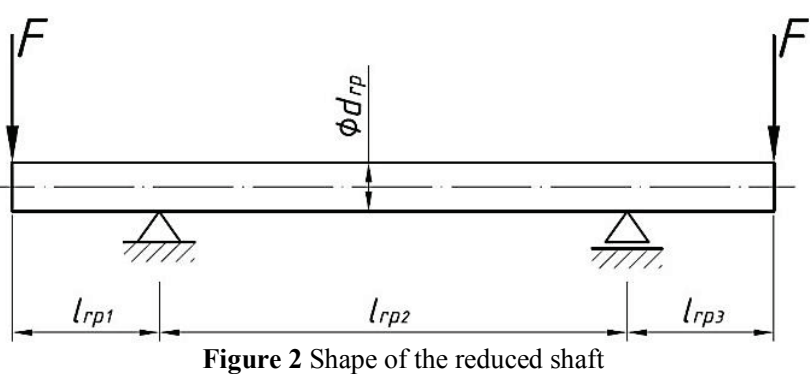

The necessary condition is the keeping of equal value at the second derivation of deflection line function, where we used Eq. (1) for the selected section.

$$
\frac{\mathrm{d}^{2} w_{(x)}}{\mathrm{d} x^{2}}=\frac{M_{\mathrm{bs}(x)}}{E \cdot J_{\mathrm{bs}}}=\frac{M_{\mathrm{rp}(x)}}{E \cdot J_{\mathrm{rp}}},\left(\mathrm{m}^{-1}\right)
$$

$M_{\mathrm{bs}(x)}$ - bending moment before reduction $(\mathrm{N} \cdot \mathrm{m})$

$M_{\mathrm{rp}(x)}-$ bending moment after reduction $(\mathrm{N} \cdot \mathrm{m})$

$J_{\mathrm{bs}} \quad-$ moment of inertia before reduction $\left(\mathrm{m}^{4}\right)$

$J_{\text {rp }} \quad-$ moment of inertia after reduction $\left(\mathrm{m}^{4}\right)$

$E \quad-$ modulus of elasticity $(\mathrm{Pa})$

By editing Eq. (1) the Eq. (2) was derived used for editing the individual section length.

$l_{\mathrm{rp}}=\sum_{i=1}^{n} l_{\mathrm{rp} i}=\sum_{i=1}^{n}\left[l_{\mathrm{bs} i} \cdot\left(\frac{d_{\mathrm{rp}}}{d_{\mathrm{bs} i}}\right)^{4}\right],(\mathrm{m})$

$l_{\mathrm{rp}} \quad-$ overall length of shaft after reduction (m)

$l_{\mathrm{rp} i}-$ length of $i^{\text {th }}$ shaft section after reduction $(\mathrm{m})$

$l_{\mathrm{bs} i}$ - length of $i^{\text {th }}$ shaft section before reduction (m)

$d_{\mathrm{rp}}-$ diameter of shaft after reduction $(\mathrm{m})$

$d_{\mathrm{bs} i}-$ diameter of $i^{\text {th }}$ shaft section before reduction $(\mathrm{m})$

After reduction, the shaft had a shape according to Fig. 2, where deflection in the places of outside load action $w_{F}$ may be computed from the Eq. (3)

$w_{F}=\frac{F \cdot l_{\mathrm{rp} 1}^{3}}{3 \cdot E \cdot J_{\mathrm{rp}}}+\frac{F \cdot l_{\mathrm{rp} 1}^{2} \cdot l_{\mathrm{rp} 2}}{2 \cdot E \cdot J_{\mathrm{rp}}},(\mathrm{m})$.

As it can be seen in the Eq. (3), the reduced length is in the cubic shape. This reduced length changes its value comparing to the primary length, depending upon diameter values. This value $l_{\mathrm{rp} 1}$ after cube power causes an expressive increasing of deflection value $w_{F}$. It brings a question, how much a deflection $w_{F}$ at reduction on different diameters $d_{\mathrm{bs} 1}, d_{\mathrm{bs} 2}$ and $d_{\mathrm{bs} 3}$ will be changed.

When computing deflection, the so-called Vereshchagin graphic-analytical method was used, where the effect of shearing force was taken into account. At properly chosen dimensions of the component, the curve radii of swings do not have a high effect on deformation and so they may be neglected [9]. The deflection Eq. (7) is derived from Eqs. (4) $\div$ (6) which represent the wellknown Castigliano method.

$w_{i}=\frac{\partial W}{\partial F_{i}},(\mathrm{~m})$

$W=\frac{1}{2 \cdot E} \int_{0}^{l} \frac{M_{(x)}^{2}}{J_{i}} \mathrm{~d} x+\frac{\kappa}{2 \cdot G} \int_{0}^{l} \frac{T_{(x)}^{2}}{A_{i}} \mathrm{~d} x,(\mathrm{~J})$

$w_{i}=\frac{1}{E} \int_{0}^{l} \frac{M_{(x)}}{J_{i}} \cdot \frac{\partial M_{(x)}}{\partial F_{i}} \mathrm{~d} x+\frac{\kappa}{G} \int_{0}^{l} \frac{T_{(x)}}{A_{i}} \cdot \frac{\partial T_{(x)}}{\partial F_{i}} \mathrm{~d} x,(\mathrm{~m})$

$w_{i}=\sum_{i=1}^{n}\left(\frac{1}{E \cdot J_{i}} \cdot A_{M i} \cdot m_{o T i}+\frac{\kappa}{G \cdot A_{i}} \cdot A_{T i} \cdot m_{t T i}\right)(\mathrm{m})$

$F_{i} \quad-$ applied force in $i^{\text {th }}$ place $(\mathrm{N})$

$W \quad$ - total strain energy of the shaft $(\mathrm{J})$

$M_{(x)}$ - bending moment $(\mathrm{N} \cdot \mathrm{m})$

$J_{i}-$ moment of inertia of $i^{\text {th }}$ section $\left(\mathrm{m}^{4}\right)$

$\kappa-$ Timoshenko coefficient for consideration of shearing force (-)

$G \quad-$ modulus of elasticity in shear $(\mathrm{Pa})$

$T_{(x)}-$ lateral force $(\mathrm{N})$

$A_{i}-$ cross-section area in $i^{\text {th }}$ cross-section $\left(\mathrm{m}^{2}\right)$

$A_{m i}$ - cross-section area under moment curve in $i^{\text {th }}$ cross-section $\left(\mathrm{N} \cdot \mathrm{m}^{2}\right)$

$m_{\mathrm{o} T i}-$ moment caused by unitary force in the place of centre of mass of $i^{\text {th }}$ surface $(\mathrm{m})$

$A_{T i}-$ cross-section area under force curve in $i^{\text {th }}$ crosssection $(\mathrm{N} \cdot \mathrm{m})$

$m_{\mathrm{t} T i}-$ shearing force caused by unitary force in the place of mass of $i^{\text {th }}$ surface (-)

The values of deflection computed without using reduction method were considered as exact. Then values of deflection were computed by PTC Creo Simulate software and compared to each other.

In comparison with deflection which is caused by outside load, many variants of diameters and lengths of individual shaft spans could be accomplished. Therefore, it was needed to introduce many limiting conditions.

The shape of analysed shaft was designed on the basis of existing shafts, found in different applications of constructional practice. It consisted of five spans containing two overhanging ends and it was supported on two bearings. According to Fig. 1 when taking shaft bearing into account, we considered with kinematics pair of pin and push fit. The limiting conditions were chosen as follows: $l_{\mathrm{bs} 1}=l_{\mathrm{bs} 5} ; l_{\mathrm{bs} 2 \mathrm{a}}=l_{\mathrm{bs} 2 \mathrm{~b}}=l_{\mathrm{bs} 4 \mathrm{a}}=l_{\mathrm{bs} 4 \mathrm{~b}}$.

These conditions provide the existence of symmetrical shaft regarding dimensions and operated load. Out of this, it is clear that computing was sufficient to act in one plane and deflection was determined at only one overhanging end.

Dimensions $d_{\mathrm{bs} 1}, d_{\mathrm{bs} 2}, d_{\mathrm{bs} 3}, l_{\mathrm{bs} 1}, l_{\mathrm{bs} 2}, l_{\mathrm{bs} 3}$ and force $F$ were chosen on the basis of real parameters found in constructional practice. Overall, there were made six variants of computing. In the first three variants, for 
diameter $d_{\mathrm{bs} 2}$ values were chosen according to the made types of bearing namely 20,40 , and $60 \mathrm{~mm}$.

According to these dimensions the assigned values of length $l_{\mathrm{bs} 2}$ were 12,15 , and $18 \mathrm{~mm}$. At each dimension $d_{\mathrm{bs} 2} 121$ variants were made, simultaneously the diameters $d_{\mathrm{bs} 1}$ and $d_{\mathrm{bs} 3}$ were changed, where conditions $d_{\mathrm{bs} 1} \leq d_{\mathrm{bs} 2}$ and $d_{\mathrm{bs} 2} \leq d_{b s 3}$ were adhered. At each variant, there was step by step made reduction of shaft diameters on the basis $d_{\mathrm{bs} 1}, d_{\mathrm{bs} 2}$ and $d_{\mathrm{bs} 3}$.

In the next three variants there were changed lengths $l_{\mathrm{bs} 1}, l_{\mathrm{bs} 2}$ and $l_{\mathrm{bs} 3}$ according to the rule of range adhering $l_{b s 1}$ $=50 \div 150 \mathrm{~mm}$ and $l_{\mathrm{bs} 3}=200 \div 400 \mathrm{~mm}$, also diameters $d_{\mathrm{bs} 1}, d_{\mathrm{bs} 2}$ and $d_{\mathrm{bs} 3}$ were changed, length $l_{\mathrm{bs} 2}$ was changed according to the previous case. From the obtained values relative percentages errors of individual methods were expressed and are shown graphically in Fig. $5 \div 10$. From these figures is created a set of assumptions presenting an obvious possibility of reduction in using on individual basis.

\section{Results}

After the substitution of chosen diameters and lengths of individual shaft span values into the Eqs. (2), (3) and (7), concrete values of shaft deflections are obtained. After comparison of values according to the methods with and without reduction, the relative percentage errors representation is computed.

Firstly, computation by the numerical method showed that our exact values of deflection somewhat respond to analytical computing, which was shown by the values from PTC Creo Simulate software, Fig. 3.

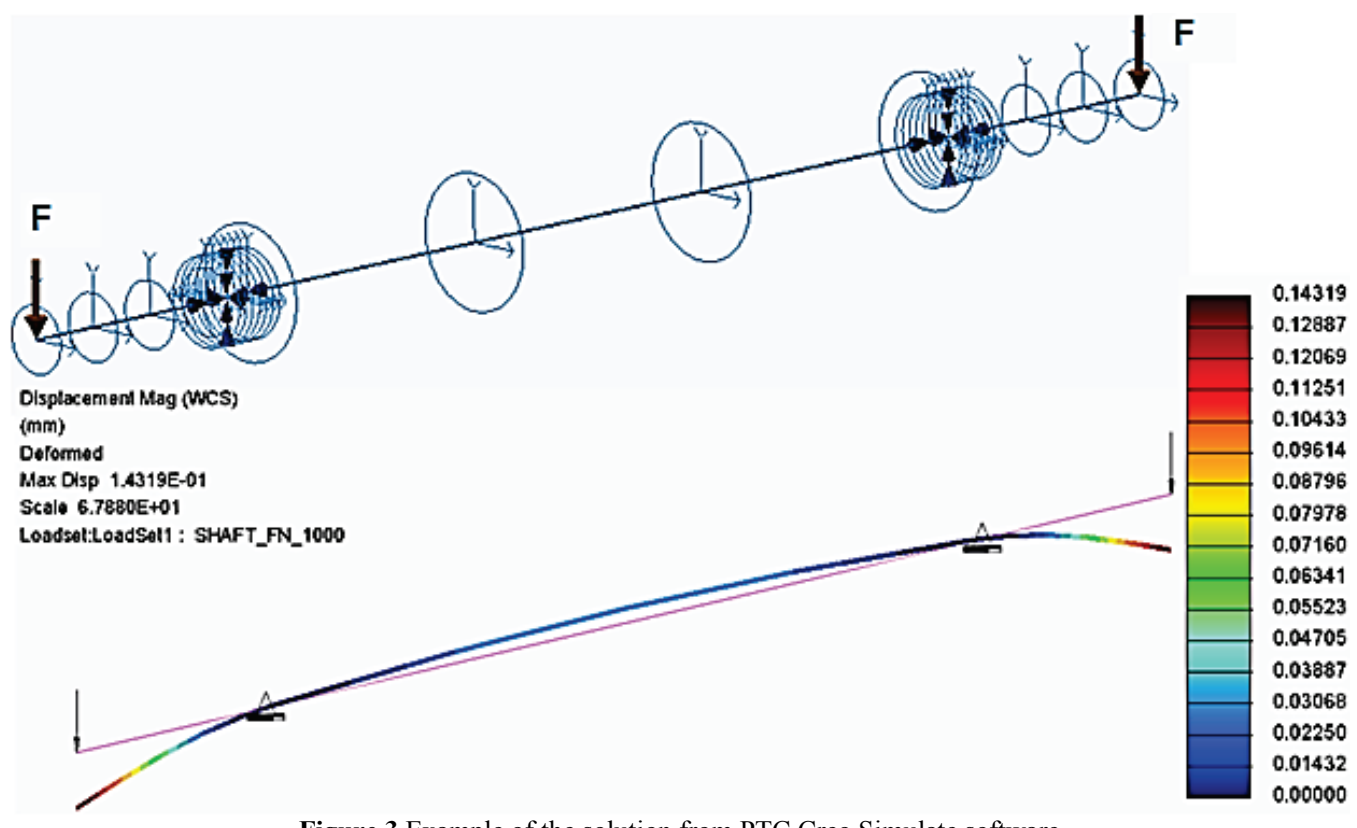

Figure 3 Example of the solution from PTC Creo Simulate software

The representation of relative percentage errors for individual variants is shown in Fig. 4 and 5 . It is obvious from this that the relative errors have values of about the tenths of percent, so it means the exact values are real.

Fig. $6 \div 8$ show dependence of the reduction method relative percentage errors at the bases $d_{\mathrm{bs} 1}, d_{\mathrm{bs} 2}$ and $d_{\mathrm{bs} 3}$

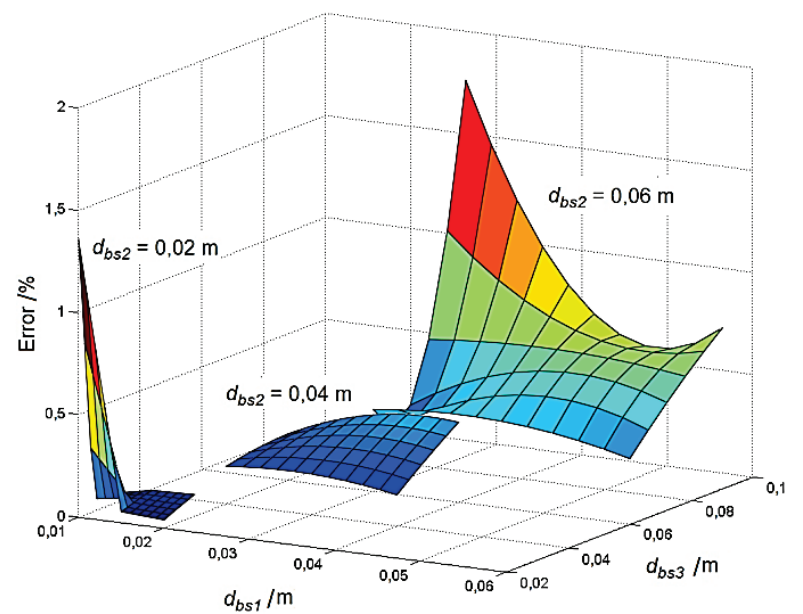

Figure 4 Dependence of numerical computing relative percentage errors for $d_{\mathrm{bs} 2}=20,40$ and $60 \mathrm{~mm}$ with using $d_{\mathrm{bs} 2}=20,40$ and $60 \mathrm{~mm}$ on the change of diameter $d_{b s l}$ and $d_{b s 3}$.

Fig. $9 \div 11$ show the logarithmic dependence of the reduction method relative percentage errors at the bases $d_{\mathrm{bs} 1}, d_{\mathrm{bs} 2}$ and $d_{\mathrm{bs} 3}$ for $l_{\mathrm{bs} 2}=12,15$ and $18 \mathrm{~mm}$ on the change of lengths $l_{\mathrm{bs} 1}$ and $l_{\mathrm{bs} 3}$.

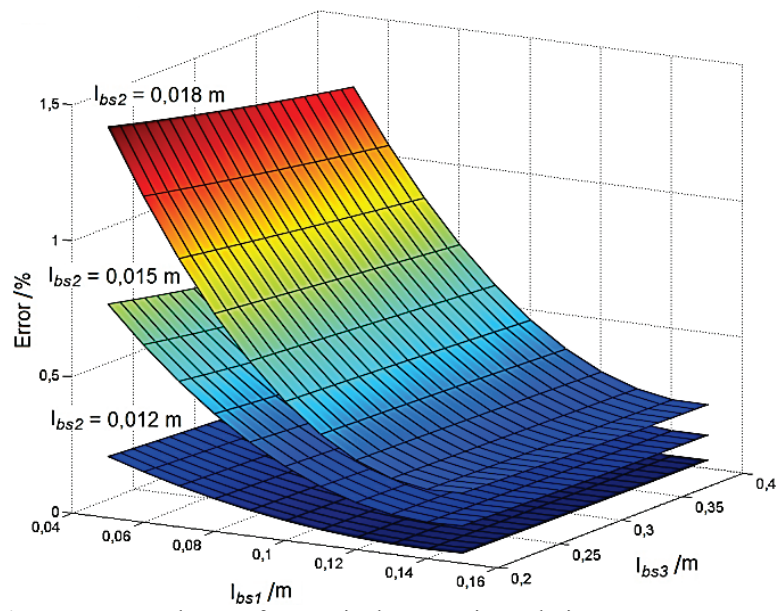

Figure 5 Dependence of numerical computing relative percentage errors for $l_{\mathrm{bs} 2}=12,15$ and $18 \mathrm{~mm}$ 


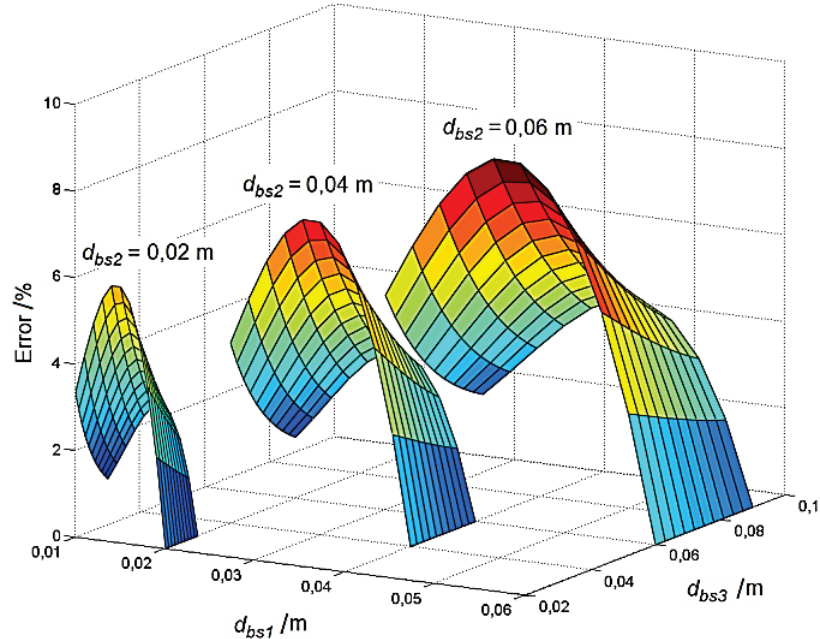

Figure 6 Dependence of the reduction method relative percentage errors at the base $d_{\mathrm{bs} 1}$ for $d_{\mathrm{bs} 2}=20,40$ and $60 \mathrm{~mm}$ on the change of diameter $d_{\mathrm{bs} 1}$ and $d_{\mathrm{bs} 3}$

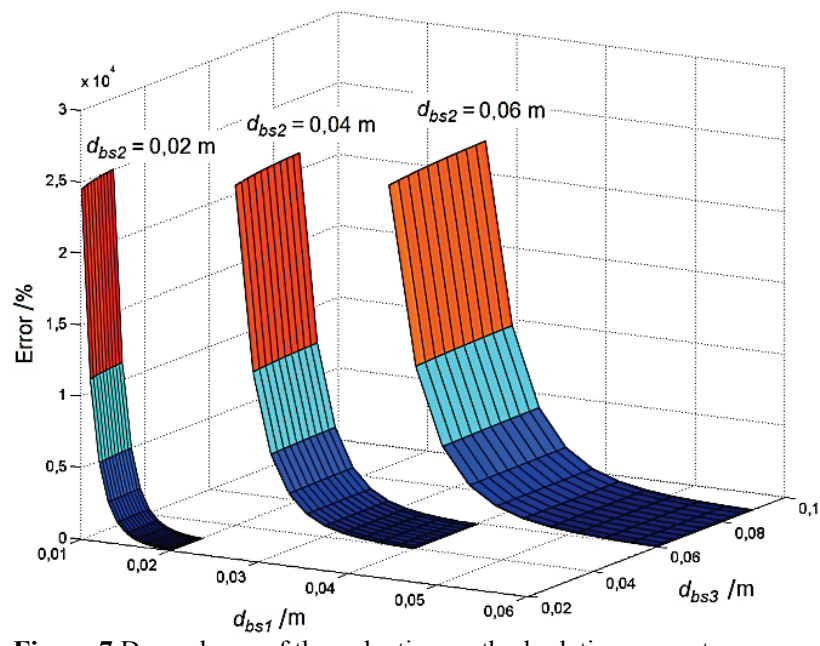

Figure 7 Dependence of the reduction method relative percentage errors at the base $d_{\mathrm{bs} 2}$ for $\mathrm{d}_{\mathrm{bs} 2}=20,40$ and $60 \mathrm{~mm}$ on the change of diameter $d_{\mathrm{bs} 1}$ and $d_{\mathrm{bs} 3}$

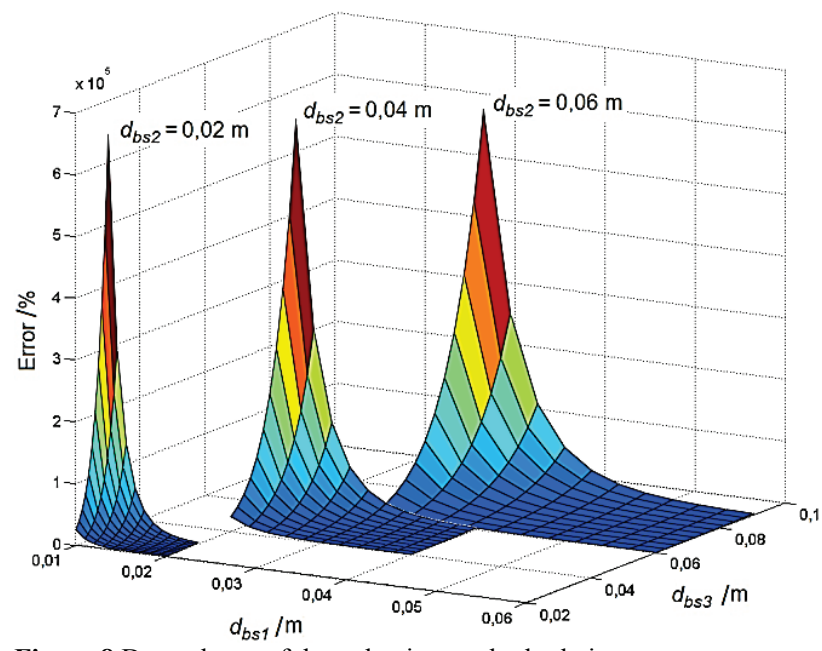

Figure 8 Dependence of the reduction method relative percentage errors at the base $d_{\mathrm{bs} 3}$ for $d_{\mathrm{bs} 2}=20,40$ and $60 \mathrm{~mm}$ on the change of diameter $d_{\mathrm{bs} 1}$ and $d_{\mathrm{bs} 3}$

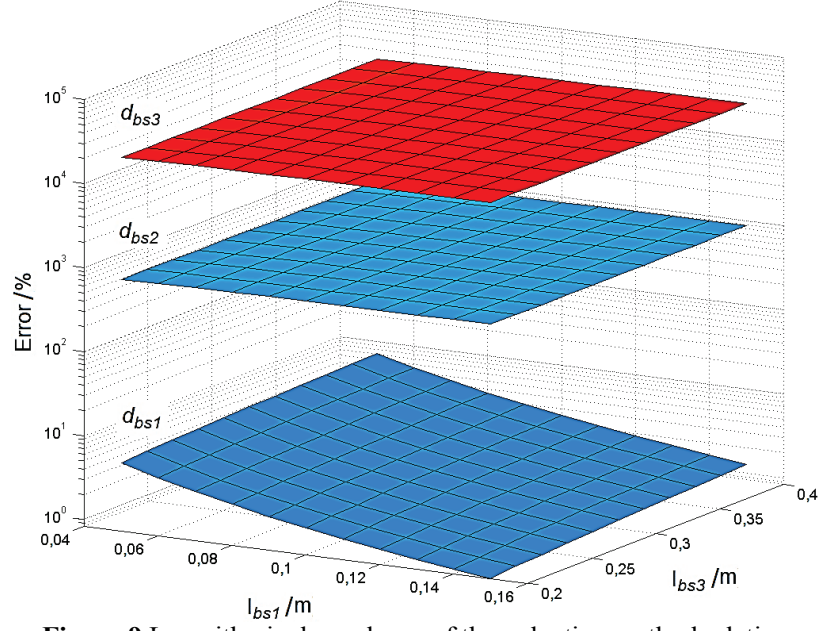

Figure 9 Logarithmic dependence of the reduction method relative percentage errors at the bases $d_{\mathrm{bs} 1}, d_{\mathrm{bs} 2}$ and $d_{\mathrm{bs} 3}$ for $l_{\mathrm{bs} 2}=12 \mathrm{~mm}$

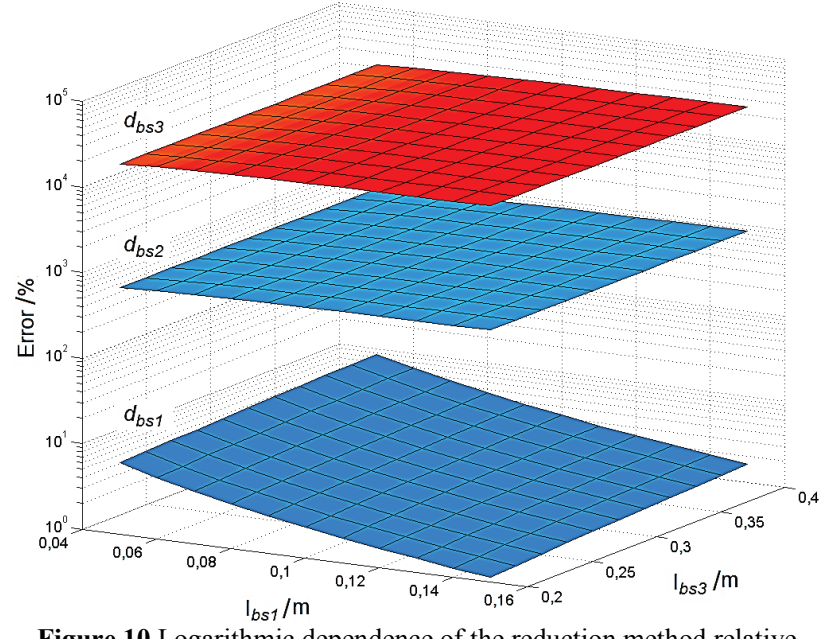

Figure 10 Logarithmic dependence of the reduction method relative percentage errors at the bases $d_{\mathrm{bs} 1}, d_{\mathrm{bs} 2}$ and $d_{\mathrm{bs} 3}$ for $l_{\mathrm{bs} 2}=15 \mathrm{~mm}$

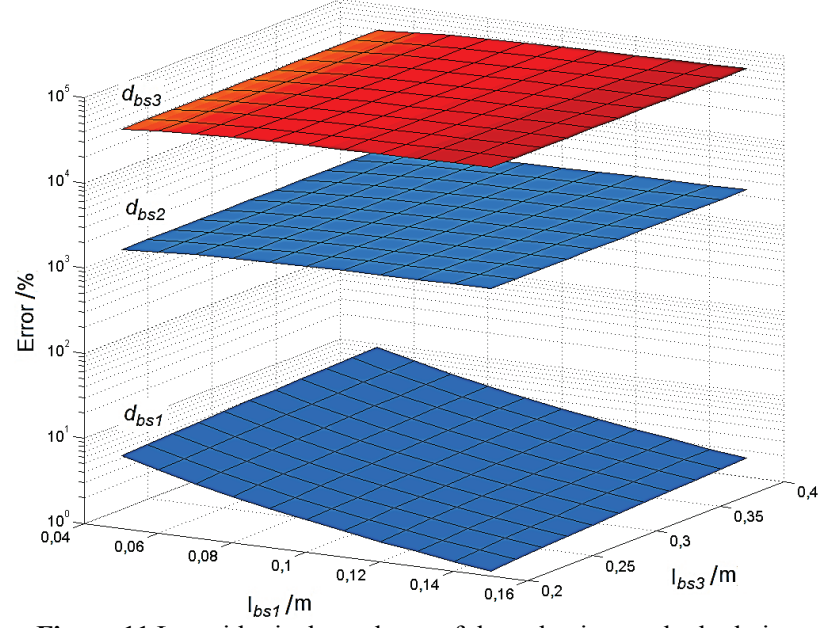

Figure 11 Logarithmic dependence of the reduction method relative percentage errors at the bases $d_{\mathrm{bs} 1}, d_{\mathrm{bs} 2}$ and $d_{\mathrm{bs} 3}$ for $l_{\mathrm{bs} 2}=18 \mathrm{~mm}$

\section{Discussion}

Based on graphics outputs one may see that only at limiting condition the relative errors higher than $5 \%$ are committed. From Fig. 6, where dependence of the relative percentage errors on a variability of the parameters $d_{\mathrm{bs} 1}$ and $d_{\mathrm{bs} 3}$ at different values $d_{\mathrm{bs} 2}$ was rated, it follows that the relative error increases with decreasing dimensions 
$d_{\mathrm{bs} 1}$, but it decreases from a certain point again. With the increasing dimension $d_{\mathrm{bs} 3}$, the relative error decreases in the whole interval. At the chosen diameters $d_{\mathrm{bs} 1}, d_{\mathrm{bs} 2}, d_{\mathrm{bs} 3}$, $l_{\mathrm{bs} 1}, l_{\mathrm{bs} 2}$ and $l_{\mathrm{bs} 3}$, the relative error did not exceed more than $9 \%$. From this figure it can be seen that with increasing diameters values, relative error increases, ratios of diameters and lengths of individual spans are related to it, since these increase with widening diameters values. It follows from this that ratio proportions between diameters and lengths of individual spans have to be minimized.

From Fig. 7, where the reduction of diameters on the base $d_{\mathrm{bs} 2}$ was performed, it follows that relative error increases with decreasing diameter $d_{\mathrm{bs} 1}$. Also, this relative error increases with increasing diameter $d_{\mathrm{bs} 3}$, but this aspect is not statistically significant. The relative error, which is committed, is relatively high at very small differences of diameters, in the order of tens percent in dependence on individual geometrical parameters values. From Fig. 8, where was performed the reduction of diameters on the base $d_{\mathrm{bs} 3}$, it was comprehended that relative error increases with decreasing of diameter $d_{\mathrm{bs} 1}$ and increasing of diameter $d_{\mathrm{bs} 3}$. Similarly as at reduction on the base $d_{\mathrm{bs} 2}$, relatively high relative errors are committed, of an order of tens to thousands percent.

From Figs. 9, 10 and 11 it follows that at reduction of diameters on the base $d_{\mathrm{bs} 1}$, the relative error increases with decreasing of length $l_{\mathrm{bs} 1}$, also with increasing of length $l_{\mathrm{bs} 3}$, but not significantly. At reduction on the base $d_{\text {bs2 }}$, respectively on $d_{\text {bs } 3}$, the relative error decreases with decreasing of length $l_{\mathrm{bs} 1}$ and increasing of length $l_{\mathrm{bs} 3}$. There is again applied the same rule as at results from Figs. 6, 7, and 8. By the reduction on the base $d_{\mathrm{bs} 1}$, the relative errors order of percent is committed, while at reduction on the bases $d_{\mathrm{bs} 2}$ and $d_{\mathrm{bs} 3}$ the error is of hundreds to thousands percent.

The next fact which was noticed, are values of deflections. At reduction of diameters on the base $d_{\mathrm{bs} 1}$, computed deflections are always smaller than deflections computed analytically. By reduction on the base $d_{\mathrm{bs} 2}$ and $d_{\mathrm{bs} 3}$, the computed deflections are higher. In the first case (reduction on the base $d_{\mathrm{bs} 1}$ ), condition is undersized, in the second and third case condition is oversized.

Based on the previous, next condition can be set and the relative errors may be eliminated. From the results it follows that the reduction of step shaft on the bases $d_{\mathrm{bs} 2}$ and $d_{\mathrm{bs} 3}$ is not suitable for practical use. In practice it is hard to find the shaft whose dimensions parameters pass the condition of very small differences among diameters, what reductions on the bases $d_{\mathrm{bs} 2}$ and $d_{\mathrm{bs} 3}$ unconditionally require. At reduction on the base $d_{\mathrm{bs} 1}$ the lowest relative errors are committed and in some cases they are theoretically acceptable. The lowest relative errors are achieved in the case of the highest or lowest differences among diameters and also the length $l_{\mathrm{bs} 1}$ should be much higher compared to the length $l_{\mathrm{bs} 2}$.

\section{Conclusion}

As it has been shown in this paper, the method of step shaft reduction is inappropriate for computing of beam deformations and similar components in an incorrectly chosen process. In the paper the step shaft consisting of five spans and containing three different diameters and lengths was analysed. By Vereshchagin method was computed the deflection in the concrete place at the ends of shaft, where this method was set as a base of correct results. This theory was compared by PTC Creo Simulate software, where the individual variants of the shaft were simulated. The relative errors that appeared between numerical and analytical computing are based on the limit of tolerance $5 \%$ and it is related to the computing algorithm of the software.

As it follows from the previous text, the unacceptability of the reduction diameter method was successfully verified in the case of non-reduction on the lowest diameter because of relative errors which oversized $5 \%$. In the case of reduction on the bases of higher diameters, at low differences among diameters high relative errors were committed. In the case of difference of $1 \mathrm{~mm}$, the relative errors are of the order of tens percent and next increase. Relative errors will not appear only in the case of shaft with one diameter along its length, but the method of reduction is not needed here.

Only one available variant is reduction on the base of the lowest diameter. In individual cases relative errors over $9 \%$ did not appear. If we want to minimize the relative errors, it is necessary to set a condition where this criterion is met. On the basis of the previous text and results it can be said the hypothesis is proven that the reduction of diameter is suitable for the shaft where differences among individual diameters are significantly high and length of overhanging end is much higher than the length of the part under bearing.

At the time of the usage of finite element method and especially computers, the classical analytical methods of deformation computing are a thing of the past. In consideration of this fact, we do not often meet with this method, respectively there exist other hand methods which are easier in their character, or they are quicker for computing. For this reason, there exist only a few literature sources which deal with it.

Because the dimensioning mistakes of this method when used in practical applications and educational process are known to us, we consider as important to remind of the limiting cases of its use, because of protection prior to fatal errors which would have negative impact on the safety and reliability of construction. Also we consider the different shaft design research as important.

\section{Acknowledgments}

The article has been written on the basis of research intention and solution of the research grant projects: VEGA No. 1/0676/14 "Technical and ecological research aimed at reducing the adverse of the operation of machinery on forest land and water", VEGA No. 1/0676/14 "Technical and ecological research aimed at reducing the adverse of the operation of machinery on forest land and water", KEGA No. 018TU Z-4/2014 "Implementation of Educational Methods for Enhancement of the Education in Field of Technical Mechanics" and KEGA No. 019TU Z-4/2015 "The innovation of forms and methods within the educational process in the field of agricultural and forest technology" 
by the Ministry of Education, Science, Research and Sport of the Slovak Republic.

\section{References}

[1] Moolwan, Ch.; Netpu, S. Failure Analysis of a Two High Gearbox Shaft. // Procedia - Social and Behaviour Sciences. $\quad 88, \quad 10(2013)$ pp. 154-163. DOl: 10.1016/j.sbspro.2013.08.491

[2] Ramesh, R.; Mannan, M. A.; Poo, A. N. Error compensation in machine tools - a review: Part I: geometric, cutting-force induced and fixture-dependent errors. // Int J Mach Tool Manu. 40, 9(2000), pp. 12351256. DOI: $10.1016 / \mathrm{S} 0890-6955(00) 00009-2$

[3] Nanda, J.; Parhi, D. R. Theoretical Analysis of the Shaft. // Advances in Fuzzy Systems, (2013), 11 pages.

[4] Tlaisi, A.; Swamidas, A. S. J.; Haddara, M. R.; Akinturk, A. Modeling and Calibration for Crack Detection in Circular Shafts Supported on Bearings Using Lateral and Torsional Vibration Measurements. // Advances in Mechanical Engineering. (2012), 18 pages.

[5] Childs, P. R. N. Mechanical Design. 2nd ed. Oxford: Elsevier Ltd., 2004.

[6] Doghri, I. Mechanics of Deformable Solid: Linear, Nonlinear, Analytical and Computational Aspects. Berlin : Springer-Verlag, 2000. DOI: 10.1007/978-3-662-04168-0

[7] Bachau, O. A.; Craig J. I. Structural Analysis, Solid Mechanics and Its Applications, Springer Netherlands, 2009.

[8] Hartsuijker, C.; Welleman, J. W. Engineering Mechanics, Stresses, Strains, Displacements, Springer Netherlands, 2007.

[9] Shigley, J. E.; Mischke, Ch. R.; Budynas, R. G. Mechanical Engineering Design, New York: The McGraw-Hill Companies Inc., 2004.

[10] Nelson H. D. A Finite Rotating Shaft Element Using Timoshenko Beam Theory. // Journal of Mechanical Design. ASME, 2009.

\section{Authors' addresses}

Stanislav Kotšmíd, Ing.

Faculty of Environmental and Manufacturing Technology, Technical University in Zvolen,

Študentská 26, 96001 Zvolen, Slovak Republic

E-mail: stanislav.kotsmid@gmail.com

\section{Ján Marienčik, PhD}

Faculty of Environmental and Manufacturing Technology,

Technical University in Zvolen,

Študentská 26, 96001 Zvolen, Slovak Republic

E-mail: jan.mariencik@tuzvo.sk

\section{Pavel Beňo, Doc. Ing. PhD}

Faculty of Environmental and Manufacturing Technology, Technical University in Zvolen,

Studentská 26, 96001 Zvolen, Slovak Republic

E-mail:pavel.beno@tuzvo.sk

\section{Marian Minárik, PhD}

Faculty of Environmental and Manufacturing Technology, Technical University in Zvolen,

Študentská 26, 96001 Zvolen, Slovak Republic

E-mail:minarik@tuzvo.sk

Dražan Kozak, Prof. dr. sc.

Mechanical Engineering Faculty in Slavonski Brod,

J. J. Strossmayer University of Osijek,

Trg Ivane Brlic Mazuranic 2, HR-35000 Slavonski Brod, Croatia

E-mail: dkozak@sfsb.hr

Pejo Konjatić, Doc. dr. sc.

Mechanical Engineering Faculty in Slavonski Brod,

J. J. Strossmayer University of Osijek,

Trg Ivane Brlic Mazuranic 2, HR-35000 Slavonski Brod, Croatia

E-mail: pekon@sfsb.hr 